\title{
Effects of Some Preservation Methods on the Nutrient and Mineral Compositions of Three Selected Edible Mushrooms
}

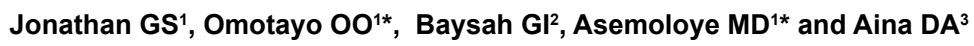 \\ ${ }^{1}$ Department of Botany, Mycology and Biotechnology Unit, University of Ibadan, Ibadan, Oyo State, Nigeria \\ ${ }^{2}$ Department of Biology, Adventist University of West Africa, West Africa
}

${ }^{3}$ Departrment of Microbiology, Babcock Univrsity, Illisan-Remo, Ogun State, Nigeria

\begin{abstract}
The global commercial mushroom production today is increasing yearly. To enhance the supply, many food processing industries normally provide a wide range of canned and processed edible mushroom products such as frozen, sterilized, dried, pickled, marinated and salted mushrooms in forms of mushroom powder, paste, concentrates and extracts. This study was therefore aimed at investigating the effects of popular preservation methods on the nutrient and mineral compositions of three selected oyster mushrooms of economic importance (Pleurotus ostreatus, Pleurotus florida and Pleurotus sajor-caju). Fresh mushroom samples were purchased from mushroom farms; each mushroom was shared into five different groups and processed as fresh, refrigerated, sundried, oven dried and micro-wave dried groups, they were thereafter analyzed for nutrient and mineral compositions. The results obtained revealed that the preservation method had significant effects on the nutrient and mineral compositions of the mushroom samples. Notably, the lowest weight values were obtained from the sundried mushroom samples while the highest value was obtained from the fresh samples. The microwave mushroom samples were richer in nutrient and mineral compositions as compared to the other three preservation methods but in all lower than the fresh samples. It is therefore concluded that the preservation methods had effects on the nutrient and mineral contents of mushrooms. However, if there is need for preservation of excess mushrooms, preservation through micro-wave drying is recommended best among the four processing methods for mushrooms preservation since it was able to retain the highest value of protein in all the studied mushrooms.
\end{abstract}

Keywords: Commercial; Production; Preservation; Edible mushroom; Nutrient; Mineral composition

\section{Introduction}

Mushrooms are the fruit bodies of fungi generally known as macrofungi [1]. They include members of Basidiomycota and some members of Ascomycota. Fleshy fruit bodies and hymenia are usually borne on gills with ephemeral structures; edible fruit bodies are commonly called mushrooms while the poisonous species are referred to as toadstools [2]. The two groups are morphologically not distinguishable but they often differ in chemical composition [3]. The number of recognized mushroom species has been reported to be 14,000 , which is about $10 \%$ of the total estimated mushroom species on earth $[1,4,5]$. The most cultivated mushrooms worldwide are Agaricus bisporus, Lentinus edodes, Pleurotus spp, Auricula auricular, Flamulina velutipes and Volvariella volvacea, they are source of nutrient and mineral salts according to Zoberi and Jonathan et al. [6-13]. These authors reported various edible mushrooms which are rich in ascorbic acid, amino acids, protein, minerals $(\mathrm{Ca}, \mathrm{P}, \mathrm{Fe}, \mathrm{K}, \mathrm{Na})$ and glycogen.

Mushrooms are free of cholesterol, contains low fat and small amount of $B$ vitamins. They are one of the few natural sources of vitamin $D$, which is essential for healthy bones and teeth. Mushrooms are a good source of $B$ vitamins for people who don't eat meat, riboflavin $\left(B_{2}\right)$, niacin $\left(B_{3}\right)$ and pantothenic acid $\left(B_{5}\right)$. These vitamins help break down proteins, fats, carbohydrate so they can be used for energy [3]. Owing to their attractive taste, aroma and nutritional values, edible mushrooms are valuable components of the diet $[14,15]$. Mushrooms have good quality proteins with lysine and tryptophan. The carbohydrates in the mushrooms are at a level of 4.5 to $5.0 \%$ but are in the form of glycogen, chitin and hemicelluloses instead of starch [13]. Mushrooms have also been used not only as a source of food but medicinal value as well [6,9-12].

The consumption of mushrooms throughout the year, particularly of mushroom species harvested in natural habitats is made possible through the use of appropriate processing methods. The food processing industry provides a wide range of canned and processed mushroom products, including frozen, sterilized, dried, pickled, marinated and salted mushrooms, mushroom powder, paste, concentrates and extracts [16-19]. Edible mushrooms in fresh, cooked or processed forms are nutritionally sound, tasteful food source for most people and can be a significant dietary supplement for vegetarians [20]. Unfortunately, freshly harvested mushrooms have short shelf life and are highly perishable, seasonal availability occurs in the case of forest mushrooms.

This chiefly concerns wild mushrooms but also applies to cultivated species $[14,21,22]$. Hence, in periods when supply exceeds demand, processing is recommended. This study is therefore aimed at investigating the effects of some available preservation methods on the nutrient and mineral compositions of three selected edible mushrooms.

*Corresponding author: Omotayo OO, Department of Botany, Mycology and Biotechnology Unit, University of Ibadan, Ibadan, Oyo State, Nigeria, Tel: +2348032306604; Email: omololaomotayo@gmail.com

Asemoloye MD, Department of Botany, Mycology and Biotechnology Unit University of Ibadan, Ibadan, Oyo State, Nigeria, Tel: +2348064844977; E-mail: asemoloyemike@gmail.com

Received August 03, 2018; Accepted September 19, 2018; Published September 21, 2018

Citation: Jonathan GS, Omotayo OO, Baysah GI, Asemoloye MD, Aina DA (2018) Effects of Some Preservation Methods on the Nutrient and Mineral Compositions of Three Selected Edible Mushrooms. J Microb Biochem Technol 10: 106-111. doi: 10.4172/1948-5948.1000402

Copyright: (c) 2018 Jonathan GS, et al. This is an open-access article distributed under the terms of the Creative Commons Attribution License, which permits unrestricted use, distribution, and reproduction in any medium, provided the original author and source are credited. 


\section{Materials and Methods}

\section{Sources of mushrooms}

Three oyster mushrooms of economic importance were selected for this study; they include Pleurotus ostreatus, Pleurotus florida and Pleurotus sajor-caj. Pleurotus ostreatus samples were purchased from a mushroom farmer at Odo-Ona, Ibadan, while Pleurotus florida and Pleurotus sajor caju were obtained from the Pathology Unit of Forestry Research Institute of Nigeria. They were identified and authenticated at the Forestry Research Institute of Nigeria (FRIN) Pathology Unit. These mushrooms were selected based on their availability at the time of this research. Sawdust of Milicia excelsa was used as cultivation substrate for P. ostreatus while sawdust of Gmelina arborea was used as cultivation substrate for P. florida and P. sajor caju.

\section{Experimental location}

The samples were prepared at the Pathology Laboratory of the Department Botany, University of Ibadan, Nigeria. Nutrient and mineral analyses of the samples were carried out at SMO consult, Ibadan, Nigeria.

\section{Sterilization of equipment}

All glass wares used in the experiment were washed with detergents, rinsed with sterile distilled water and allowed to dry except the $250 \mathrm{ml}$ extraction flask which was dried in the oven at $105-110^{\circ} \mathrm{C}$. Working benches were sterilized by swabbing them with cotton wool soaked with $70 \%$ ethanol.

\section{Experimental design}

The freshly harvested mushroom samples were analyzed at the stage of collection; they were subjected to different processing methods and then re-analyzed after a period of time to observe the effect of processing methods on their mineral contents. Immediately after the procurement of the freshly harvested edible mushrooms, each mushroom was shared into five different groups representing fresh, refrigerated, sundried, oven dried and micro-wave dried groups. The groups for refrigeration were kept in a plastic container and refrigerated at $4^{\circ} \mathrm{C}$ for 5 days in a refrigerator manufactured by Midea Industries, the sundried groups were left to dry in the open air for 5 days, the oven-dried groups were dried in an oven manufactured by Masterchef industries at $50^{\circ} \mathrm{C}$ for 48 hours while the micro-wave dried groups were dried at $40^{\circ} \mathrm{C}$ for 48 hours in a micro-wave manufactured by Eurosonic industries.

These mushrooms were mashed each with mortal into flake-form before they were digested and analyzed in the laboratory according to each mushrooms and groups. The freshly harvested groups as controls were mashed with mortal into paste form and analyzed immediately for nutrient analysis and mineral contents. The experiment was done in triplicates in Complete Randomized Design (CRD).

\section{Nutrient analysis}

Determination crude protein: The crude protein in the samples was determined through the estimation of total nitrogen by Kjeldahl procedure. The amount of crude protein was obtained by multiplying the nitrogen content by 6.25 . This factor was based on the assumption that all feed proteins contain $16 \%$ nitrogen and nitrogen present in the tissue is presented as protein. The protein content may vary in nitrogen content from 13 to $18 \%$.

Determination of total nitrogen: The total Nitrogen was determined according to the method of Bradstreet [23]. $0.2 \mathrm{~g}$ of each mushroom sample was weighed carefully into the digestion tubes to ensure that all sample materials got to the bottom of the tubes. Kjeldahl catalyst was added followed by the addition of $5 \mathrm{ml}$ of Conc. $\mathrm{H}_{2} \mathrm{SO}_{4}$ and digested at $350^{\circ} \mathrm{C}$ until the solution becomes clear. The block was removed from the digester to cool. About $50 \mathrm{ml}$ distilled water was added and the content was mixed vigorously. The mixture was poured into a $100 \mathrm{ml}$ flask and made up to mark. The flask was properly shaken and allowed to cool and settle down.

Determination of crude fat: The crude fat in the samples was determined according to the method of AOAC [24]. The fat content in plant tissues is generally extracted with petroleum ether using Soxhlet extraction method. The volatile oils and resins are of little nutritional value. $1 \mathrm{gm}$ of each dried sample was weighed into fat free extraction thimble and pug lightly with cotton wool. The thimble was placed in the extractor and fitted up with reflux condenser and a $250 \mathrm{ml}$ soxhlet flask, which has been previously dried in the oven at $105-110^{\circ} \mathrm{C}$ and cooled in the dessicator. The soxhlet flask was then filled to $3 / 4$ of volume with petroleum ether (b.pt $40^{\circ} \mathrm{C}-60^{\circ} \mathrm{C}$ ), and the soxhlet flask. Extractor plus condenser set was placed on the heater. The heater was put on for six hours with constant running water from the tap for condensation of ether vapour. The set was constantly watched for ether leaks and the heat source is adjusted appropriately for the ether to boil gently. The ether was left to siphon over several times say over at least $10-12$ times until it is short of siphoning. It was after this was noticed that any ether content of the extractor was carefully drafted into the ether stock bottle. The thimble containing sample was then placed into the condenser and extracted for about 5-6 hours. The flask containing the fat was detached, its exterior cleaned and dried to a constant weight in the oven.

\section{Calculation}

- Weight of empty thimble $=\mathrm{W}_{\mathrm{o}}$

- Weight of thimble + ground sample $=\mathrm{W}_{1}$

- Weight of ground sample $=\mathrm{W}_{1}-\mathrm{W}_{\mathrm{o}}$

- Weight of empty extraction flask $=\mathrm{W}_{2}$

- Weight of extraction flask + ether $=\mathrm{W}_{3}$

- Weight of ether (fat or oil)

$$
\% \text { fat }=\frac{\mathrm{W}_{3}-\mathrm{W}_{2}}{\mathrm{~W}_{1}-\mathrm{W}_{\mathrm{o}}} \times 100
$$

Determination of crude fibre: The crude fibre was determined according to the method of Cuniff [25]. $0.50 \mathrm{~g}$ of the ground sample was weighed into a 1 litre conical flask ( $\mathrm{W}_{\mathrm{o}}$ ). $200 \mathrm{ml}$ of boiling $1.25 \%$ $\mathrm{H}_{2} \mathrm{SO}_{4}$ was added and boiled gently for 30 minutes using cooling fingers to maintain a constant volume. The mixture was filtered through muslin cloth stretched over $9 \mathrm{~cm}$ Buchner funnel and was rinsed well with hot distilled water. The material was scraped back into flask with spatula. $200 \mathrm{ml}$ of boiling $1.25 \%$ of $\mathrm{NaOH}$ was added and allowed to boil gently for another 30 minutes using cooling fingers to maintain a constant volume. The mixture was filtered through muslin cloth and the residue was washed thoroughly with hot distilled water, rinsed once with $10 \% \mathrm{HCl}$ and again with industrial methylated spirit. The mixture was finally rinsed three times with petroleum ether $\left(\mathrm{BP} 40-60^{\circ} \mathrm{C}\right)$ and allowed to drain dry. The residue was scraped into a crucible, dried overnight $105^{\circ} \mathrm{C}$ in the oven and cooled in the desiccator. The sample was weighed $\left(\mathrm{W}_{1}\right)$ and dried to ash at $550^{\circ} \mathrm{C}$ for 90 minutes in muffle furnace, cooled in a desiccator and weighed again $\left(\mathrm{W}_{2}\right)$. 


\section{Calculation}

$$
\% \text { Crude fibre }=\frac{\mathrm{W}_{1}-\mathrm{W}_{2}}{\mathrm{~W}_{\mathrm{o}}} \times 100
$$

Determination of soluble carbohydrate: The soluble carbohydrate was determined using the nitrogen-free extraction procedure of FAO [26]. The nitrogen-free extractive (NFE) referred to as soluble carbohydrate is not determined directly but obtained as a difference between crude protein and the sum of ash, crude fat and crude fibre.

$\mathrm{NFE}=100-(\%$ ash + crude fibre $+\%$ crude fat + crude protein $)$.

Determination of moisture: The moisture in the samples was determined according to the method of AOAC [24]. The moisture in the samples was determined according to the method of AOAC [24]. The weight of the empty crucible was taken $\mathrm{W}_{\mathrm{o}}, 2 \mathrm{~g}$ of the sample was added into the crucible and it was weighed $\left(\mathrm{W}_{1}\right)$. The sample and crucible was placed in the drying oven and dried at $105-110^{\circ} \mathrm{C}$ for 24 hours, and cooled in a desiccators. The weight of the crucible with the dried sample was taken $\mathrm{W}_{2}$ and it was further dried for another 24 hours to make sure the drying was complete and was weighed again.

\section{Calculation:}

$$
\text { Moisture }=\frac{\mathrm{W}_{1}-\mathrm{W}_{2}}{\mathrm{~W}_{1}-\mathrm{W}_{\mathrm{o}}} \times 100
$$

Determination of ash: The determination of ash was carried out according to the method described by AOAC [24]. The empty crucible was weighed $\mathrm{W}_{\mathrm{o}}$ and $2 \mathrm{~g}$ of the sample was added into it and weighed as well $\left(\mathrm{W}_{1}\right)$. The sample in the crucible was placed in the muffle furnace to ash at $500-600^{\circ} \mathrm{C}$ and cooled in the dessicator. The crucible and the ash sample was weighed $\mathrm{W}_{2}$.

$$
\% \text { Ash }=\frac{\mathrm{W}_{1}-\mathrm{W}_{0}}{\mathrm{~W}_{1}-\mathrm{W}_{\mathrm{o}}} \times 100
$$

\section{Analysis of the mineral compositions}

Mineral analyses of some metal ions were carried out following the procedure of Jonathan et al. [27]. $0.5 \mathrm{~g}$ of the sample was weighed into the digestion tubes. $10 \mathrm{ml}$ of $\mathrm{HNO}_{3} / \mathrm{HClO}_{4}$ acid $(2: 1)$ was added to it. It was digested at $150^{\circ} \mathrm{C}$ for one and a half hours. The temperature was increased to $230^{\circ} \mathrm{C}$ and $2 \mathrm{ml}$ of $\mathrm{HCl} /$ Distilled $\mathrm{H}_{2} \mathrm{O}(1: 1)$ was added and heated for another 30 minutes. The mixture was removed from heat, allowed to cool before been washed into a standard $100 \mathrm{ml}$ volumetric flask and made up to the mark with distilled water. Potassium, sodium and calcium were determined by flame photometry from wet digestion. Magnesium, zinc and iron were determined by Atomic Absorption Spectrophotometry from wet digestion.

\section{Statistical data analysis}

The data obtained was analysed using SPSS version 16 and mean was separated by Duncan's multiple range test (DMRT).

\section{Results and Discussion}

The results of the various analyses of the samples showed that the preservation methods had significant effects on the nutrient and mineral compositions of the mushroom samples (Tables 1 and 2); all the samples had higher moisture content when fresh and refrigerated (Tables 3-5). Mushrooms are generally high in moisture content, which are approximately $90 \%$ of their fresh weight after harvest. This accounts for their short shelf life as they deteriorate easily [28-30]. It was observed that the fresh samples are richer in nutrient and mineral contents as compared to the processed samples. Mushrooms are considered good source of superior quality protein with well distributed essential amino acids [31]. The lowest weight value was obtained from the sundried sample of $P$. florida (Table 5) while the highest value was obtained from the fresh sample of $P$. florida. This agrees with the observation made

\begin{tabular}{|c|c|c|c|c|c|c|c|}
\hline Source of variation & DF & Calcium & Magnesium & Potassium & Sodium & Iron & Zinc \\
\hline Preservation & 4 & $2.87^{* *}$ & $13.77^{\star *}$ & $62.94^{* *}$ & $28.38^{\star *}$ & $7.84^{* *}$ & $2.57^{\star *}$ \\
\hline Mushrooms & 2 & $43.20^{* *}$ & $868.71^{* *}$ & $1348.67^{* *}$ & $3640.21^{* *}$ & $23.48^{* *}$ & $11.51^{* *}$ \\
\hline Errors & 30 & 0.74 & 1.19 & 0.19 & 0.39 & 0.15 & 0.05 \\
\hline Total & 45 & & & & & & \\
\hline
\end{tabular}
by James which indicated that protein content of edible mushroom in dry weight is about $19-40 \%$ [32].

${ }^{* *}=$ highly significant, ${ }^{*}=$ significant, $n s=$ not-significant $(p>0.05)$

Table 1: Mean Square Effects of preservation on nutrient composition of the mushroom.

\begin{tabular}{|c|c|c|c|c|c|c|c|}
\hline Source of variation & DF & Crude Protein & Crude Fat & Crude Fibre & Total Ash & Moisture content & Carbohydrate \\
\hline Preservation & 4 & $52.79^{* *}$ & $0.55^{* *}$ & $5.81^{* *}$ & $132.00^{* *}$ & $18571.79^{* *}$ & $125.09^{* *}$ \\
\hline Mushrooms & 2 & $6.91^{* *}$ & $0.19^{* *}$ & $1.56^{* *}$ & $0.49^{* *}$ & $2.28^{*}$ \\
\hline Errors & 30 & 1.27 & 0.43 & 0.76 & 0.004 & 0.51 \\
\hline
\end{tabular}

\begin{tabular}{|c|c|c|c|c|c|c|c|}
\hline & Crude Protein & Crude Fat & Crude Fibre & Total Ash & Carbohydrate & Moisture Content & Dry Matter \\
\hline Fresh & $28.71 \pm 0.61^{\mathrm{a}}$ & $2.87 \pm 0.17^{\mathrm{a}}$ & $8.47 \pm 0.24^{a}$ & $1.11 \pm 0.03^{c}$ & $58.48 \pm 0.98^{b}$ & $90.71 \pm 0.03^{a}$ & $9.28 \pm 0.03^{c}$ \\
\hline Refrigerated & $25.47 \pm 0.82^{c}$ & $2.10 \pm 0.15^{c}$ & $6.55 \pm 0.18^{c}$ & $0.88 \pm 0.02^{d}$ & $61.74 \pm 6.18^{a}$ & $92.20 \pm 0.02^{\mathrm{a}}$ & $7.79 \pm 0.02^{d}$ \\
\hline Sundried & $23.58 \pm 0.09^{d}$ & $2.26 \pm 0.14^{b}$ & $7.00 \pm 0.02^{b}$ & $7.21 \pm 0.03^{b}$ & $63.15 \pm 5.33^{a}$ & $8.81 \pm 0.02^{b}$ & $91.18 \pm 0.02^{b}$ \\
\hline Oven-dried & $23.58 \pm 0.09^{d}$ & $2.45 \pm 0.05^{b}$ & $6.81 \pm 0.03^{b}$ & $9.13 \pm 0.02^{\mathrm{a}}$ & $58.16 \pm 0.92^{b}$ & $6.05 \pm 0.07^{c}$ & $93.95 \pm 0.07^{a}$ \\
\hline Micro-waved & $26.32 \pm 0.22^{b}$ & $2.68 \pm 0.03^{a}$ & $6.88 \pm 0.04^{b}$ & $9.18 \pm 0.02^{a}$ & $57.65 \pm 0.39^{c}$ & $8.02 \pm 0.03^{b}$ & $91.98 \pm 0.03^{b}$ \\
\hline
\end{tabular}

${ }^{* *}=$ highly significant, ${ }^{*}=$ significant, $n s=$ not-significant $(p>0.05)$

Table 2: Mean Square Effects of preservation on mineral composition of the mushrooms.

Values with the same letter in each column are not significantly different at $(P<0.05)$.

Table 3: Effect of different preservation methods on nutrient composition of Pleurotus oestratus. 
Fresh mushrooms usually contain less fat, the amount being $1-8 \%$ of dry weight $[20,30]$. Fat content of $P$. sajor caju in the present study showed different values from the reported value by Chang et al. who reported lower fat content in $P$. sajor caju, that is between 1.7$2 \%$ compared to other mushrooms however, fat content of $P$. sajor caju in this study was higher $(2.88 \%)$ compared to $P$. florida which is lower (2.57\%) [33]. Available carbohydrate is second major nutrient component of mushrooms.

The findings from the result also showed that refrigerated mushroom samples were richer in nutrient and mineral compositions as compared to the other three preservation methods (Tables 3-5) and this agrees with the report of who observed higher carbohydrate content in refrigerated mushrooms [34]. Furthermore, when comparing dried mushroom to fresh or refrigerated mushrooms, protein content of fresh mushrooms were higher than the refrigerated and the dried mushrooms. From this study, $P$. florida and P. ostreatus were both significantly different in crude protein (Table 1), this is in accordance with the finding of Pehrsson et al., Zahid et al. and Jonathan et al. [30,35,36]. Ash content was found to be highest in the micro-waved sample of $P$. sajor-caju (Table 4) while it was lowest in the fresh sample of $P$. ostreatus (Table 3) is not in agreement with the report of $c$ who observed higher ash content in fresh sample of mushrooms than the preserved sample.

\begin{tabular}{|c|c|c|c|c|c|c|c|}
\hline & Crude Protein & Crude Fat & Crude Fibre & Total Ash & Carbohydrate & Moisture Content & Dry Matter \\
\hline Fresh & $26.25 \pm 1.11^{a}$ & $2.88 \pm 0.26^{a}$ & $7.15 \pm 0.67^{a}$ & $1.96 \pm 0.08^{c}$ & $61.74 \pm 1.48^{b}$ & $89.11 \pm 0.70^{\mathrm{a}}$ & $10.89 \pm 0.70^{\circ}$ \\
\hline Refrigerated & $23.16 \pm 0.43^{c}$ & $2.25 \pm 0.34^{c}$ & $6.35 \pm 0.27^{b}$ & $1.82 \pm 0.04^{c}$ & $66.42 \pm 0.98^{a}$ & $90.98 \pm 0.15^{\mathrm{a}}$ & $9.01 \pm 0.15^{c}$ \\
\hline Sundried & $22.67 \pm 1.15^{d}$ & $2.61 \pm 0.33^{b}$ & $6.54 \pm 0.03^{b}$ & $7.21 \pm 0.04^{b}$ & $60.95 \pm 0.48^{b}$ & $7.75 \pm 1.16^{b}$ & $91.25 \pm 0.11^{\mathrm{b}}$ \\
\hline Oven-dried & $24.14 \pm 0.10^{b}$ & $2.77 \pm 0.14^{b}$ & $6.84 \pm 0.08^{\mathrm{a}}$ & $8.96 \pm 0.15^{\mathrm{a}}$ & $57.28 \pm 0.31^{c}$ & $6.55 \pm 1.13^{c}$ & $94.09 \pm 0.09$ \\
\hline Micro-waved & $24.20 \pm 0.23^{b}$ & $2.94 \pm 0.04^{a}$ & $6.82 \pm 0.06^{a}$ & $9.21 \pm 0.05^{\mathrm{a}}$ & $56.82 \pm 0.32^{c}$ & $7.79 \pm 0.15^{b}$ & $92.22 \pm 0.13^{b}$ \\
\hline
\end{tabular}

Values with the same letter in each column are not significantly different at $(P<0.05)$

Table 4: Effect of different preservation methods on nutrient composition of Pleurotus sajor caju.

\begin{tabular}{|c|c|c|c|c|c|c|c|}
\hline & Crude Protein & Crude Fat & Crude Fibre & Total Ash & Carbohydrate & Moisture Content & Dry Matter. \\
\hline Fresh & $28.77 \pm 4.02^{\mathrm{a}}$ & $2.57 \pm 0.46^{b}$ & $6.52 \pm 0.65^{\mathrm{a}}$ & $1.92 \pm 0.04^{c}$ & $62.74 \pm 0.78^{b}$ & $88.62 \pm 1.76^{\mathrm{b}}$ & $11.35 \pm 1.76^{b}$ \\
\hline Refrigerated & $24.97 \pm 0.16^{c}$ & $2.39 \pm 0.14^{c}$ & $5.81 \pm 0.24^{b}$ & $1.86 \pm 0.04^{c}$ & $61.69 \pm 8.97^{\mathrm{b}}$ & $91.13 \pm 0.06^{a}$ & $8.86 \pm 0.06^{c}$ \\
\hline Sundried & $21.97 \pm 0.13^{c}$ & $2.24 \pm 0.08^{c}$ & $6.56 \pm 0.04^{a}$ & $7.32 \pm 0.04^{b}$ & $64.56 \pm 4.81^{\mathrm{a}}$ & $8.97 \pm 0.04^{c}$ & $91.02 \pm 0.04^{a}$ \\
\hline Oven-dried & $23.75 \pm 0.07^{b}$ & $2.69 \pm 0.07^{a}$ & $6.88 \pm 0.03^{a}$ & $8.73 \pm 0.07^{a}$ & $59.33 \pm 2.40^{c}$ & $6.05 \pm 0.07^{d}$ & $93.94 \pm 0.07^{a}$ \\
\hline Micro-waved & $23.77 \pm 0.25^{b}$ & $2.78 \pm 0.03^{a}$ & $6.77 \pm 0.08^{a}$ & $9.18 \pm 0.02^{\mathrm{a}}$ & $57.65 \pm 0.39^{c}$ & $7.93 \pm 0.08^{c}$ & $92.22 \pm 0.13^{a}$ \\
\hline
\end{tabular}

Values with the same letter in each column are not significantly different at $(P<0.05)$

Table 5: Effect of different preservation methods on nutrient composition of Pleurotus florida.

\begin{tabular}{|c|c|c|c|c|c|c|}
\hline & Calcium & Magnesium & Sodium & Potassium & Iron & Zinc \\
\hline Fresh & $26.48 \pm 0.04^{a}$ & $128.77 \pm 0.27^{a}$ & $150.96 \pm 0.13^{a}$ & $953.60 \pm 0.54^{a}$ & $20.57 \pm 0.54^{a}$ & $2.98 \pm 0.07^{a}$ \\
\hline Refrigerated & $26.08 \pm 0.10^{b}$ & $127.07 \pm 0.09^{b}$ & $148.02 \pm 0.10^{c}$ & $951.93 \pm 0.16^{b}$ & $18.01 \pm 0.13^{c}$ & $1.96 \pm 0.19^{c}$ \\
\hline Sundried & $25.01 \pm 0.09^{c}$ & $125.50 \pm 0.15^{d}$ & $145.20 \pm 0.75^{c}$ & $950.69 \pm 0.68^{c}$ & $18.51 \pm 0.51^{c}$ & $1.48 \pm 0.17^{c}$ \\
\hline Oven-dried & $25.52 \pm 0.02^{c}$ & $126.95 \pm 0.24^{b}$ & $148.61 \pm 0.17^{b}$ & $950.89 \pm 0.96^{c}$ & $18.64 \pm 0.95^{c}$ & $1.98 \pm 0.11^{c}$ \\
\hline Micro-waved & $26.07 \pm 0.11^{b}$ & $126.28 \pm 0.40^{c}$ & $148.92 \pm 0.40^{b}$ & $952.14 \pm 2.24^{b}$ & $19.64 \pm 0.41^{b}$ & $2.10 \pm 0.40^{b}$ \\
\hline
\end{tabular}

Values with the same letter in each column are not significantly different at $(P<0.05)$.

Table 6: Effect of different preservation methods on mineral composition of Pleurotus sajor caju.

\begin{tabular}{|c|c|c|c|c|c|c|}
\hline & Calcium & Magnesium & Sodium & Potassium & Iron & Zinc \\
\hline Fresh & $24.57 \pm 0.09^{a}$ & $137.45 \pm 0.37^{a}$ & $129.05 \pm 0.07^{a}$ & $974.27 \pm 0.25^{a}$ & $18.03 \pm 0.06^{a}$ & $3.60 \pm 0.24^{a}$ \\
\hline Refrigerated & $23.09 \pm 0.07^{b}$ & $135.80 \pm 0.23^{c}$ & $125.04 \pm 0.10^{b}$ & $972.20 \pm 0.33^{b}$ & $16.00 \pm 0.07^{c}$ & $2.31 \pm 0.32^{c}$ \\
\hline Sundried & $21.07 \pm 0.07^{d}$ & $135.32 \pm 0.22^{c}$ & $123.01 \pm 0.13^{c}$ & $963.23 \pm 0.89^{d}$ & $16.77 \pm 0.04^{b}$ & $3.38 \pm 0.03^{b}$ \\
\hline Oven-dried & $21.01 \pm 0.03^{d}$ & $128.86 \pm 0.13^{d}$ & $122.13 \pm 0.63^{d}$ & $964.39 \pm 0.51^{d}$ & $15.93 \pm 0.32^{d}$ & $3.49 \pm 0.10^{a}$ \\
\hline Micro-waved & $23.89 \pm 0.01^{c}$ & $136.04 \pm 0.07^{b}$ & $124.89 \pm 0.15^{b}$ & $968.79 \pm 1.18^{c}$ & $16.96 \pm 0.05^{b}$ & $3.51 \pm 0.06^{a}$ \\
\hline
\end{tabular}

Values with the same letter in each column are not significantly different at $(P<0.05)$

Table 7: Effect of different preservation methods on mineral composition of Pleurotus ostreatus. 
Citation: Jonathan GS, Omotayo OO, Baysah GI, Asemoloye MD, Aina DA (2018) Effects of Some Preservation Methods on the Nutrient and Mineral Compositions of Three Selected Edible Mushrooms. J Microb Biochem Technol 10: 106-111. doi: 10.4172/1948-5948.1000402

\begin{tabular}{|c|c|c|c|c|c|c|}
\hline & Calcium & Magnesium & Sodium & Potassium & Iron & Zinc \\
\hline Fresh & $23.27 \pm 0.11^{a}$ & $121.01 \pm 0.98^{a}$ & $120.64 \pm 0.56^{a}$ & $970.90 \pm 0.24^{a}$ & $18.13 \pm 0.10^{a}$ & $2.17 \pm 0.11^{a}$ \\
\hline Refrigerated & $22.00 \pm 0.05^{c}$ & $120.28 \pm 0.29^{b}$ & $118.01 \pm 0.07^{c}$ & $965.90 \pm 0.15^{c}$ & $17.03 \pm 0.05^{b}$ & $1.95 \pm 0.08^{b}$ \\
\hline Sundried & $22.87 \pm 0.04^{b}$ & $118.38 \pm 0.57^{c}$ & $116.46 \pm 0.27^{d}$ & $966.75 \pm 1.91^{b}$ & $16.51 \pm 0.58^{d}$ & $1.87 \pm 0.25^{c}$ \\
\hline Oven-dried & $22.57 \pm 0.02^{b}$ & $115.17 \pm 1.75^{d}$ & $118.27 \pm 1.49^{c}$ & $964.18 \pm 1.27^{d}$ & $16.84 \pm 0.19^{d}$ & $1.98 \pm 0.45^{b}$ \\
\hline Micro-waved & $22.99 \pm 0.12^{a}$ & $120.19 \pm 0.30^{b}$ & $119.47 \pm 1.84^{b}$ & $966.30 \pm 0.89^{b}$ & $17.59 \pm 1.93^{c}$ & $2.04 \pm 0.12^{a}$ \\
\hline
\end{tabular}

Values with the same letter in each column are not significantly different at $(P<0.05)$

Table 8: Effect of different preservation methods on mineral composition of Pleurotus florida.

(16.96) and zinc (3.51) in P. ostreatus, the highest content of calcium (26.07), sodium (148.92), potassium (952.14) and zinc (2.10) in $P$. sajor-caju. This shows that the minerals were not significantly affected by the heat from the micro-wave, compared to other preservation methods. This is not in agreement with the report of Ayodele et al. who observed that sun-drying method of preservation was able to retain more minerals in mushrooms [41].

However, sun-drying method of preserving mushrooms was found to have retained the highest content of carbohydrate in $P$. florida and $P$. ostreatus. This agrees with the report of Ayodele et al. [41].

Mineral content of Pleurotus species varied considerably in all the preservation methods, the values were significantly close to the values of the fresh mushroom samples, indicating that the preservation methods were effective in retaining the mineral content of the mushrooms [42]. The results indicated that the micro-wave method of preservation was the best in retaining the nutrient and mineral content of the Pleurotus species followed by the refrigeration method.

\section{Conclusion}

The preservation methods had effects on the nutrients and mineral content of the mushrooms with irrespective of the species as they showed lower reduced nutrient and mineral compositions as compared to the fresh samples. However, among the preserved mushroom samples, the refrigerated samples had higher carbohydrate, moisture content, magnesium, sodium and potassium contents while microwave preserved mushrooms had higher in crude protein, ash, fat, calcium, sodium, zinc, and potassium. Therefore, it is concluded that the fresh mushrooms are better than preserved mushrooms. However, if there is need for preservation for excess mushrooms, preservation through micro-wave drying is the best since it was able to retain the highest value of protein and this is recommended for preservation of mushrooms.

\section{References}

1. Cheung PCK (2008) Mushrooms as Functional Foods. John Wiley \& Sons, Inc. 3: 23-24.

2. Ramsbottom J (1989) Mushrooms and Toadstools. London: Bloomsbury Books pp: 51-55.

3. Adedayo MR (2011) Proximate Analysis on four edible mushrooms. J Appl Sci Environ Manage 15: 9-11.

4. Jonathan SG, Ogunsanwo OB, Asemoloye MD, Baysah GI, Omotayo OO (2018) Biocontrol Efficacy of Ginger (Zingiber officinale) Fortification on the Nutrient and Aflatoxin Compositions of 'Ogi'. Researcher 10: 46-55.

5. Jonathan SG, Bello TS, Asemoloye MD (2017) Food Values, Spoilage Moulds and Aflatoxin Detection in 'Attiéké' (A Cassava Fermented Product). J Microb Biochem Technol 9: 244-248.

6. Aida FM, Shuhaimi NA, Yazid MM, Maaruf AG (2009) Mushroom as a potential source of prebiotics: a review. Trends in Food Science and Technology 20: 67-575.

7. Jonathan SG, Ajayi I, Omitade Y (2011) Nutritional Compositions, fungi and aflatoxin detection in stored 'gbodo' (fermented Discorea rotundata) and 'elubo ogede' (fermented Musa parasidiaca) from south western Nigeria. Afr J Food Sci 5: 105-110.

8. Jonathan SG, Oyetunji OJ, Olawuyi OJ, Asemoloye MD (2012) Growth responses of Corchorus olitorius Lin. (Jute) to the application of SMC as an organic fertilizer. Academ Arena 4: 48-56.

9. Jonathan SG, Okoawo EE, Asemoloye MD (2016) Fungi and Aflatoxin Contamination of Sausage Rolls. IJSRK 4: 099-104.

10. Jonathan SG, Adeniyi MA, Asemoloye MD (2016) Nutrient Value, Fungal Biodeterioration, and Aflatoxin Contamination of Suya Spices a Novel Nigerian Indigenous Snacks. Hindawi Scientifica 4602036.

11. Jonathan SG, Asemoloye MD, Abe A, Olawuyi OJ, Aina D (2016) Food Value Fungi and Aflatoxin Detection in Stored 'Orunla' Abelmoschus esculentus L. (Moench) from Ibadan, Nigeria. Researcher 8: 7-18.

12. Jonathan SG, Popoola K, Olawuyi OJ, Ajiboye M, Oyelekan AO (2012) Insect and Fungal Pests of some mushrooms collected from University of Ibadan, Nigeria campus. Nature and Science 10: 142-147.

13. Duyff R (2006) American Dietetic Association's Complete Food and Nutrition Guide. Third edition. Wiley \& Sons. NJ. Pp: 252-254.

14. Czapski J (2003) Evaluation of chemical composition of commercially canned mushrooms processed from fresh and desalted mushrooms and derived from different geographic region. Veg Crops Res Bull 58: 135-141.

15. Vetter J (2003) Chemical Composition of fresh and conserved mushroom. Eur Food Res Technol 217: 10-12.

16. Bakowski J, Michalik H (1982) Estimation of firmness of carrot, Celeriac Parsley, Onion, Leek and Mushrooms for the production of dehydrated veges. Biul Warz 26: 337-360.

17. Vivar-Quintana AM, Gonzales-San Jose ML, Collado-Fernandez M (1999) Influence of canning process on colour, weight and grade of mushrooms. Food Chem 66: 87-92

18. Kondratowicz J, Kowalko P (2000) Mrozenic grzybow w skroplonym azocie (Freezing mushrooms in liquid nitrogen). Chlodnictwo 35: 48-50.

19. Czapski J (2000) Stored mushrooms quality as affected by specificity of film packaging. Veg Crops Res. Bull 53: 111-124.

20. Breene W (1990) Nutritional and medicinal value of speciality mushrooms. J Food Production. 53: 883-894.

21. Burton KS, Noble R (1993) The influence of flush number, bruising and storage temperature on mushroom quality. Post Biol Technol 3: 39-47.

22. Tseng YH, Mau JL (1999) Contents of sugar, Free amino acids and free 5nucleotides in mushrooms, Agaricus bisporus, during post-harvest storage. J Sci Food Agric 79: 1519-1523.

23. Bradstreet RB (1965) The Kjeldahl Method of Organic Nitrogen. Academic Press, New York. 45-47.

24. AOAC (2008) Official Methods of Analysis. $20^{\text {th }}$ edition, Washington DC

25. Cuniff $P$ (1995) Official methods of analysis of AOAC International. $16^{\text {th }}$ ed. Gaithersburg: AOAC International 60-62.

26. FAO (2003) Food and Agriculture Organization, Food and Nutrition paper, 77, ISSN 0254-4725. Food energy- methods of analysis and conversion factor, Report of the technical workshop, Rome 2002.

27. Jonathan SG, Oyetunji OJ, Asemoloye MA (2012) Influence of spent mushroom compost (SMC) of Pleurotus ostreatus on the yield and nutrient compositions of Telfairia occidentalis Hook. FA. (Pumpkin), a Nigerian leafy vege. Nature and Science 10: 149-156. 
Citation: Jonathan GS, Omotayo OO, Baysah GI, Asemoloye MD, Aina DA (2018) Effects of Some Preservation Methods on the Nutrient and Mineral Compositions of Three Selected Edible Mushrooms. J Microb Biochem Technol 10: 106-111. doi: 10.4172/1948-5948.1000402

28. Beyer M (1996) The impact of the mushroom Industry on the environment. Mushroom News 44: 6-13.

29. Fasidi IO, Kadiri M (1993) Use of agricultural waste for the cultivation Lentinus subnudus (Polyporales:Polyporaceae) in Nigeria Rev Biol Trop 41: 411-415.

30. Kim KM, Ko JA, Lee JS, Park HJ, Hanna MA (2006) Effect of modified atmosphere packaging on the shelf-life of coated, whole and sliced mushrooms. Food Science and Technology 39: 365-372.

31. Zahid K, Barua S, Haque I (2010) Proximate Composition and Mineral Content of Selected Edible Mushroom. Bangladesh J Nutrition 22: 61-68.

32. Patil SS, Ahmed SA, Telang SM, Baig MMV (2010) The nutritional value of Pleurotus ostreatus (Jacq. Fr.) Kumm. cultivated on different lignocellulosic agro-wastes. Innovative Romanian Food Biotechnology 7: 66-76.

33. James CS (1995) Analytical Chemistry of Foods $1^{\text {st }}$ edn, Chapman and Hall, New York. 67-72.

34. Chang ST, Lau OW, Cho KY (1981) The cultivation and nutritive value of Pleurotus sajor-caju. Eur J Applied Microbio and Biotech 12: 58-62.

35. Oei P (1991) Manual on Mushroom cultivation. Tool Foundation Amsterdam 49-50.
36. Pehrsson PR, Haytowitz DB, Holden JM (2003) The USDA's National Food and Nutrient Analysis Program: Update 2002. J Food Comp Anal 16: 331-341.

37. Jonathan SG, Bello TS, Asemoloye MD (2017) Food Values, Spoilage Moulds and Aflatoxin Detection in 'Attiéké' (A Cassava Fermented Product). J Microb Biochem Technol 9: 244-248.

38. Chandravadana MV, Vekateshwarlu G, Bujji Babu CS, Roy TK, Shivashankara $\mathrm{K}$, et al. (2005) Volatile flavour components of dry milky mushrooms (Calocybe indica). Flavour and Fragrance J 20: 715-717.

39. Plaza JL, Alique R, Zamorano JP, Calvo ML, Navaro MJ (1995) Effect of high permeability to 02 on the quality changes and shelf-life of fresh mushrooms stored under modified atmosphere packing. Mush Sci 14: 709-716.

40. Gupta S (1998) Mineral element contents of edible mushrooms. Journal of Mycology and Plant Pathology 28: 353-354.

41. Asemoloye MD, Jonathan SG, Sadaf R, Habiba ZO, koawo EE, et al. (2017) Incidence and Chemical Implications of Aflatoxin in Street-Vended Foods. Aflatoxin-Control, Analysis, Detection and Health Risks.

42. Ayodele SM, Emmanuel FP, Agianaku OF (2011) Comparative Studies of sun, smoke and oven-drying methods on the nutrient contents of four wild edible mushrooms in Nigeria. J Nat Prod Plant Resour 1: 70-74. 